\title{
Ver-se y ser visto. Una interpretación de las escenas de recompensa en la narrativa funeraria amarniana: la audiencia 'habilitante'
}

Silvana Yomaha*

\section{Resumen}

En época amarniana el ritual de aparición en público del faraón a través de la ventana del palacio, acompañado por la familia real, puede ser interpretado como un dispositivo de control monárquico pero también como un componente performativo de las prácticas sociales. Resulta fundamental la experiencia propedéutica debido a que es en el seno de este acto público - plasmado en las paredes de las tumbas privadas de los funcionarios de la corte- en donde se escenifican las relaciones políticas, sociales, económicas y fundamentalmente simbólicas que caracterizan al reinado de Akhenatón. El objetivo de este artículo es analizar la entrega de bienes de sustento y objetos de lujo de manos del faraón a sus servidores más fieles como un ritual. Se pretende demostrar la eficacia del poder material y simbólico de la monarquía sostenida por una burocracia y por la divinidad Atón. Todo esto se manifiesta en la representación de la escena de entrega de recompensas a sacerdotes, generales y administradores desde la ventana de aparición y ante la presencia de una audiencia configurada por espectadores clave (embajadores extranjeros, burócratas, sacerdotes, soldados, la comunidad en general), para completar la efectividad del acto.

To see and be seen. An interpretation of the reward scenes in the Amarnian funerary narrative: the 'enabling' audience

\begin{abstract}
In the Amarnian era, the ritual of the public appearance of the pharaoh through the palace window, accompanied by the royal family, can be interpreted as a monarchical control device but also as a performative component of social practices. The instructive experience is fundamental because it is within this public act-depicted on the walls of the court officer private tombs- that the political, social, economic, and fundamentally symbolic relationships that characterize the Akhenaten's reign, are shown. The main goal of this paper is to analyze the delivery of livelihoods and luxury items from
\end{abstract}

Recibido: 11 de junio de 2019

Aceptado:

8 de diciembre de 2019

\section{Palabras clave}

Antiguo Egipto Epigrafía funeraria Performance

\section{Keywords}

Ancient Egypt Funerary epigraphy Performance

"Centro de Investigaciones “M. Saleme de Burnichon", Facultad de Filosofía y Humanidades, Universidad Nacional de Córdoba (UNC). Av Haya de la Torre s/n, Pabellón Agustín Tosco, $1^{\circ}$ piso, Ciudad Universitaria (CP 5000), Córdoba, Argentina. E-mail: syomaha.sy@gmail.com 
the hands of the pharaoh to his most faithful servants as a ritual. It is intended to demonstrate the effectiveness of the material and symbolic power of the monarchy sustained by the bureaucracy and by the Aton divinity. All of this is manifested in the representation of the scene of giving rewards to priests, generals, and administrators from the window of appearance in the presence of an audience set up by key spectators (foreign ambassadors, bureaucrats, priests, soldiers, the community in general) to complete the effectiveness of the act.

“(...) Salud a Nefer-kheperu-ra, el Atón [quien establece] la humanidad y los convierte en generaciones!” (Davies 1908, VI, p. 12)

\section{Premisas introductorias}

En el antiguo Egipto, el reformismo amarniano se basó en la adaptación y resignificación de las "bases intelectuales" del estado faraónico (Kemp, 1992). En este sentido, la apropiación de la fuerza vital por excelencia, el sol, y la identificación de toda vida como procedente del disco solar implicó una revisión de los preceptos fundamentales de la teología solar y la adecuación del culto osiríaco en un intento por posicionar al dios Atón como creador y ordenador cósmico (Teeter, 2011). Las prácticas habilitantes para la vida en el Más Allá se expresaron en la composición de una narrativa funeraria que centró su eje de visibilidad en la familia real y en la comunidad que con su presencia legitimaba y contribuía al circuito de redistribución de la fuerza vital (Yomaha, 2005). El monarca era el representante del orden y el equilibrio (maat); en su figura se reúnen los opuestos y se instaura una armonía relativamente inalterable. Sin embargo, la permanencia y armonía cósmica dependían en gran medida de la fuerza del faraón y es por ello que en períodos de inestabilidad política se acentúa la necesidad de recordar el papel del rey como conciliador de orden y desorden, en permanente conflicto.

En este artículo se abordarán las imágenes de la muerte como motivación de la praxis humana de la imagen, a entender de Belting (2007). El concepto de "medio" opera en el sentido de corporizar la imagen y, por ello, las escenas a analizar serán presentadas como "portadoras de imagen", "contenedoras" de la imagen del difunto, "(...) una presentación que se ha materializado simétricamente en una representación" (Belting, 2007, p. 183, cursivas del autor). Además, se pretende presentar un tratamiento más integral de la visualidad como una dimensión importante de la vida social y los procesos históricos, esto es la percepción del potencial cognitivo de la imagen. Siguiendo a Ulpiano Bezerra de Menezes (2003) el estudio de los registros visuales con perspectiva histórica admite proponer algunas premisas para la consolidación de una historia visual como un conjunto de recursos operativos para mejorar la coherencia de la investigación histórica. El objeto de análisis en este artículo lo constituye una selección de las escenas de entrega de recompensas en el marco de la ventana del palacio, por la cual aparecía el faraón Akhenatón, con la reina Nefertiti y, en ocasiones, con la familia real. Estas imágenes integran la decoración de las paredes de las tumbas rupestres cuyos propietarios fueron los nobles de la ciudad de Amarna. El fundamento de la selección de fuentes se circunscribe a la visualización de la entrega del collar del honor de manos del monarca y el conteo de las raciones (Ezzamel, 2002, 2009) respectivas como práctica efectiva de recompensar al funcionario partidario de la reforma.

Pretendemos analizar la relación entre el faraón Akhenatón y quienes se muestran en las tumbas como sus servidores más fieles, para comprender la dinámica de alianzas que se establecieron durante el período amarniano, a sabiendas de que las imágenes presentan y comunican una idealización de estas relaciones de poder. El abordaje 
se realizará aplicando la metodología iconológica de Panofsky $(1972,2000)$ ya que respecto de su morfología y carácter, las escenas que estudiamos son marcadamente iconográficas pero tienen textos asociados que deben considerarse como una unidad de significado. Para Panofsky las imágenes son pasibles de ser analizadas a partir del acto interpretativo que implican tanto la lectura del sentido fenoménico de la imagen, es decir la iconología, como su significado iconográfico y la inferencia de su contenido esencial como expresión de valores de época.

La percepción de la imagen y el texto como partes constitutivas de un componente expresivo multivalente puede comprenderse en el Egipto faraónico como el aspecto visible de su cosmovisión. Asumimos que la conciencia histórica de los egipcios tendió a conservar, a modo de reservorio patrimonial, los modelos estéticos en los que texto y contexto conforman una unidad de significado que se identifica desde época predinástica. En este sentido, si entendemos la mentalidad egipcia en tanto constructo inmerso en un sistema de don y contra don, advertimos que es el rey quien debía mostrar su capacidad de cuidar los recursos creados por obra divina y, al mismo tiempo, corresponder al dios con la propia construcción de un mundo ordenado y ofrendarle periódicamente. La tumba, precisamente, permite visualizar este cosmos regulado sobre la base de un aparato reciprocitario. En las tumbas de nobles del período amarniano ${ }^{1}$, se observa una narración de correspondencia entre el faraón y los nobles; de ahí que éstos incluyan en sus tumbas "manifestaciones icónicas" (Alvarado, 2006) de las actividades que realizó el faraón y a la vez cómo esos nobles contribuyeron al mantenimiento del sistema de reciprocidad y redistribución del aparato estatal egipcio.

El monumento funerario no era una obra de arte para el egipcio, tal como se manifiesta ante nuestros ojos posmodernos. En su sepulcro el funcionario pretendía relatar los acontecimientos más relevantes de su vida ${ }^{2} \mathrm{y}$, a través de esa expresión, perpetuar el favor divino del que fue merecedor e interven,ir en la dinámica cósmica cumpliendo sus obligaciones ritualistas. Se generaba así una comunicación entre el macrocosmos universal y el microcosmos funerario y la intención se centra en inferir cómo operaban los discursos y las situaciones de interacción social que éstos inducían (Gillam, 2005). El ascenso de Akhenatón al trono conllevó la constitución de una corte integrada por funcionarios adeptos al sistema reformista. Estos dignatarios, al trasladarse a Amarna, decoraron sus tumbas con la impronta de las preferencias del monarca.

En vez de gozar de las atenciones de su familia, ver pasar las horas en su propiedad agrícola y asegurarse de estar familiarizado con algunos de los dioses del mundo subterráneo, ahora el dueño de la tumba observaba con humildad y adoración mientras la familia real veneraba al Atón y se paseaba por la capital. En la intimidad de tu tumba, el nuevo proyecto de Akhenatón amenazaba con estar contigo para siempre. (Kemp, 1992, p. 399).

En efecto, en el interior de la tumba se representaban los acontecimientos cosmogónicos de acuerdo con los fundamentos míticos habilitando prácticas para la repetición del acontecer inicial. La disposición arquitectónica y la distribución de las escenas en cada tumba indican un sentido ajustado a esta percepción del cosmos en un nivel macro y uno más reducido; de ahí que cada escena representada deba necesariamente ser "leída" y comprendida en relación con las escenas contiguas, teniendo en cuenta el concreto histórico del que la tumba es un monumento manifestante. Consideramos oportuno aplicar el concepto de "agencia del objeto" (Gell, 1998) atendiendo a los modos en que un artefacto es capaz de afectar a las personas, movilizando respuestas emocionales, generando ideas y provocando una variedad de acciones y procesos sociales, en la intención de interpretar las articulaciones entre cosas, personas y prácticas culturales.
1. Correspondiente al gobierno de Amenofis IV en el período 1353-1336 a.C., según Hornung (2000), una vez que modificó su nombre y titulatura por el de Akhenaton y emprendió el traslado de la capital del estado a la ciudad de Amarna.

\author{
2. Nos referimos al denominado \\ "género autobiográfico" o \\ "biografías" que, de acuerdo con \\ Lichtheim (1988), da cuenta de las \\ estrategias de legitimación que \\ este tipo de textualidad comporta \\ en referencia a los aspectos \\ narrativos presentes y a los códigos \\ de representación de la época. \\ En este sentido, recuperamos el \\ concepto de 'estilo epocal' de \\ Erwin Panofsky (2000).
}


3. La existencia de la ventana de aparición ha sido probada arqueológicamente en los templos de Tebas Occidental por la ubicación y reconocimiento de los peldaños en el interior de los palacios templo, los que dan acceso a la ventana de aparición que se abría desde el sur de la sala hipóstila del palacio a la entrada del patio del templo, por ejemplo

el Templo de Ramsés III de Medinet Habu (Badawi, 1966). Es probable que en los templos funerarios de Hatshepsut (Naville, 1908, lám. CXIX), Sethi I (Städelman, 1973, p. 229), Ramsés II (Hölscher, 1931, p. 77), Merenptah (O’Connor, 1998, pp. 167-198), y Ramsés III (Hölscher, 1931, pp. 39 ss) las respectivas ventanas de aparición tuvieran una clara función cultual (Städelman, 1973), puesto que podrían ser interpretadas como un marco de oficialidad de la ritualización llevada a cabo frente a ella, a la manera del 'cielo' en donde el rey 'resplandece', en clara alusión al disco solar.
Sabemos que los rituales, caracterizados convencionalmente, son formas actuadas de creencias que están insertas en una estructura predeterminada, pero se resignifican en la acción misma de su actualización. Para Víctor Turner un ritual es una performance, ya que es

(...) el drama social que brota de la suspensión del juego de los roles normativos. Su actividad apasionada elimina la distinción normal entre el fluir y la reflexión, ya que el drama social se convierte en un asunto de urgencia que reclama la reflexión sobre la causa y el motivo de la acción que daña el tejido social (Geist, 2002, p. 129).

En época amarniana la aparición en público del faraón acompañado por la familia real a través de la ventana del palacio, puede ser interpretado como uno de los elementos que Barry Kemp (1992, p. 347) denomina el “escenario de la pompa real”. El autor analiza los componentes del contexto público de aparición del rey como un líder carismático puntualizando: 1) la comitiva oficial; 2) la escolta armada; 3) ademanes de deferencia especial por parte de aquellos a quienes se permite acercarse; 4) la "aparición", solo o acompañado de la familia, en el balcón del palacio; 5) pasar revista a las tropas y los representantes del imperio en público; 6) actos de culto públicos o semipúblicos y 7) los retratos del líder, solo o en familia, en las casas particulares de la gente (Kemp, 1992). La tumba de Parennefer, en la que Kemp basa su descripción, es uno de los sepulcros en los que se visualizan los registros de la audiencia que abordaremos aquí (Davies, 1903-1908, pl. IV). Al respecto, acordamos con Belting (2007, p. 56) cuando afirma que una imagen es más que un producto de la percepción, e indica acerca del medio: "No era la cualidad técnica sino el uso cultural, lo que definía al medio en su historia. El espectador ejercitaba aquí no solamente su propia mirada al mundo, sino también la expansión de su imaginación.” Así, la imagen:

Se manifiesta como resultado de una simbolización personal o colectiva. Todo lo que pasa por la mirada (...) puede entenderse así como imagen, o transformarse en una imagen (...) las propias imágenes pueden considerarse como medios del conocimiento, que de otra forma se manifiestan como textos. Pero se hacen visibles mediante técnicas o programas, que en retrospectiva histórica pueden llamarse medios portadores (Belting, 2007, pp. 14-15).

A escala iconográfica, la decoración y los textos registrados en las tumbas de los funcionarios proporcionan los elementos a partir de los cuales se comprende la expresión de la ceremonia de otorgar la recompensa a la manera de un ritual. Nuestro interés se circunscribe al reinado de Akhenatón porque es en el contexto reformador donde se evidencia un desarrollo profuso del tema iconográfico, llegando a alcanzar su máxima expresión en la época de auge del movimiento renovador amarniano. Según nuestra interpretación, la representación de entrega de la recompensa resalta por su importancia nucleadora de la narrativa en contexto funerario, debido a que es en el seno de este acto público donde se "escenifican" las relaciones políticas, sociales, económicas y fundamentalmente simbólicas que caracterizan al llamado período amarniano.

El objetivo de la ritualización consistía en la redistribución de bienes de sustento y objetos de lujo de manos del faraón a sus servidores más fieles, especialmente generales y administradores, desde la ventana de aparición ${ }^{3}$ (Martin, 1993) y en presencia de las embajadas extranjeras que concurrían a presentar la tributación - y relevo de cautivos(Anthes, 1930 en Kemp, 1992) y efectivización de la promoción de funcionarios (Hölscher, 1931). La representación de la ceremonia de recompensa remite sin duda a una práctica concreta y palpable a través de los testimonios arqueológicos de los que actualmente disponemos (Kemp, Stevens, Dabbs, Zabecki y Rose, 2013), así como también las referencias que los funcionarios dejaron asentadas en las estelas privadas, 
en particular refiriendo su presencia en el momento de la ceremonia y cuando se recompensaba a uno de sus pares (Schulman, 1988).

Las representaciones de entrega de recompensas simbolizaban la universalización de las relaciones y la visión egipcia del cosmos (Galán, 2009). Aún más, reforzaban la posición social y cósmica de los funcionarios ya que en sus tumbas se presentaba un microcosmos como un espacio público, a la vista de todos, escenificado en un contexto oficial que se desarrollaba dentro de la estructura del palacio y en la cual revestía vital relevancia el acto de "ver" para "pertenecer".

Teniendo en cuenta estos referentes teóricos y metodológicos, los objetivos que nos proponemos son, en primera instancia, comprender la importancia del período de la reforma amarniana en la construcción de una política de reestructuración interna como consecuencia del imperialismo propio del Reino Nuevo egipcio. Para ello resulta imperioso establecer la naturaleza y funcionalidad de las ceremonias que han sido representadas en las tumbas de la necrópolis de Amarna y, en este sentido, atender a la entrega de la recompensa en la ventana de aparición como un ritual expuesto a modo indicativo de acciones performativas.

En el relato que representa la decoración funeraria se resaltó la posibilidad de "ser visto" con el objeto de incrementar las distancias jerárquicas entre los niveles sociales y, principalmente, entre el monarca y sus nobles 4 . "La producción de imágenes ha tenido siempre por efecto una estandarización de las imágenes individuales y, por su parte las creó a partir del mundo de imágenes contemporáneo de sus observadores, el que sólo entonces hizo posible el efecto colectivo" (Belting, 2007, p. 26).

\section{Imagen y monumento}

Las tumbas, en tanto monumentos informativos, refieren acerca de la ejecución de ceremonias públicas (Schulman, 1988) presididas por el rey y en las cuales el funcionario tomaba parte como respuesta a su actividad burocrática.

El trasfondo religioso que envuelve las ceremonias representadas en las tumbas privadas retoma, en época amarniana, un fundamento mítico que justifica y legitima la actualización de un acto fundacional primigenio. La justificación de la relación filial entre el disco solar y el monarca se expuso en los muros de las tumbas amarnianas de los nobles, en textos conocidos como Himnos Breves e Himno Extenso a Atón (Rosenvasser, 1972). Akhenatón incluyó en su titulatura real el epíteto "el que vive de Maat", significando con ello que el exclusivo garante del orden cósmico era él, Akhenatón, como "hijo de Atón" y elegido para desempeñar esa función equilibradora. El Himno a Atón inscripto en la tumba de Ay en Amarna (TA $\left.{ }^{5} 25\right)$ evidencia esta personalización de maat (Davies, 1908). Entendemos que ello implica una decisión autocrática de reafirmar la figura regia inserta en un programa reformista de tipo conservador.

Las escenas - imagen representante e imagen representada (Belting, 2007) - se componen del elemento narrativo que se desarrolla a partir del diálogo introducido con la frase "palabras dichas", y se presenta gráficamente con los nombres del hablante y del interlocutor cara a cara (Zingarelli, 2010). Las representaciones de la ceremonia de recompensar al funcionario serán abordadas desde la perspectiva del ritual con el objeto de mostrar la dimensión simbólica ligada a la dimensión material con que se exhiben las composiciones arquitectónicas y epigráficas, tanto textuales como pictóricas.

"Por medio de las imágenes y de los rituales que se realizaban ante éstas, el espacio social se expandía en torno del espacio de los muertos y desde ahí establecía un nuevo
4. Un antecedente importante es la representación de la entrega de recompensa en la tumba de Khaemhet (TT57), en Tebas. El artista encargado de la decoración de la tumba de Khaemhet seguramente recibió precisas indicaciones para destacar la figura del propietario de la tumba y diferenciarlo respecto de sus pares. Estos se encuentran representados semi inclinados, con las manos tocando sus rodillas flexionadas, mirando hacia abajo (Wreszinski, 1988), en actitud de sumisión hacia el monarca. La figura de Khaemhet, de mayor tamaño que el resto pero intencionalmente menor que la del faraón, en talla jerárquica, se encuentra parado tocando con su mano izquierda un gran collar de oro que ha sido colocado en su cuello como signo de honor y status. Las tumbas tebanas del visir Ramose (TT55) (Hodel-Hoenes, 200o) y el príncipe, padre y favorito del dios, ministro real del Norte Parennefer (TT188) (Davies, 1923), quienes desempeñaron sus cargos bajo Amenofis III y Amenofis IV-Akhenatón (Davies, 1941), presentan signos indicadores del proceso reformista en este sentido, por cuanto la recompensa es entregada individualmente.

5. En adelante la sigla TA refiere a las tumbas de la necrópolis de Amarna. 
6. De acuerdo con Ezzamel (2002), desde los albores de la era dinástica en Egipto se registra la labor del escriba como una de las ocupaciones más estimadas y de gran prestigio social. significado que aseguraba el espacio vital." (Belting, 2007, p. 181). Por lo general, cuando el espacio lo permitía, una tumba rupestre contenía los siguientes elementos arquitectónicos: un ante patio, una o varias estancias y una fosa que bajaba desde el ante patio o desde una de las salas hasta la cámara funeraria (Dodson e Ikram, 2008; Manniche, 1994). Ahora bien, la configuración completa de una tumba comprende por lo menos dos dimensiones: la del diseño arquitectónico y la de su decoración. La forma de ' $\mathrm{T}$ ' invertida que presenta una tumba típica del período del imperio debe ser analizada entonces a partir de estas magnitudes y pueden establecerse nexos significativos entre ambas. Acerca de los espacios de representación, las inscripciones e imágenes plasmadas en los vestíbulos (salas transversales que dinamizaban y restringían las vías de circulación y movimiento de quienes visitaban el monumento) de las tumbas rupestres estaban destinadas a la circulación de los propios funcionarios encargados de la inspección como un dispositivo de control y disciplinamiento, a partir del ejemplo del burócrata que obtuvo el favor real para exhibir tales escenas e inscribir los textos en las paredes de su sepulcro ${ }^{6}$. "De este modo, la muerte, que por naturaleza es asocial, se convirtió en un elemento del orden social. (...) Como es bien sabido, la muerte debe buscarse entre los vivos, que gustan tanto de administrarla" (Belting, 2007, p. 196).

Estas tumbas pertenecían a personas particulares que ocupaban altas posiciones en la estructura social y política y si bien se puede pensar que por ello eran recintos más modestos que los de los miembros de la realeza, hubo un progresivo aumento en el tamaño y diseño de las mismas según el status del difunto (Dodson e Ikram, 2008). Así, el primer destinatario de la tumba rupestre era el difunto; no obstante, tras su entierro, el monumento era un reservorio documental destinado a informar a la elite y a la familia del propietario, un ámbito de desarrollo de diversas actividades cultuales y ceremonias rituales. Dice Belting:

Era justamente la animación lo que otorgaba vida a la imagen, vida que estuvo siempre latente en la encarnación de la imagen. Si la praxis mágica cayó en desuso la imagen ya sólo podía ser un medio para el recuerdo. Pero incluso el recuerdo, ejercido por los medios propios del espectador, era otra manera de encarnación en imagen (Belting, 2007, p. 185).

El aspecto arquitectónico y de diseño puede ser analizado como paratexto y el interior de la tumba, es decir, la composición de las escenas y los textos, su ubicación y correlato, como texto. El paratexto se refiere a la naturaleza polimorfa del monumento, en el aspecto icónico y estructural (Alvarado, 2006), en tanto el texto, soportado en el paratexto, forma parte de un código estético que se presenta en su dimensión ideográfica inscripta en la piedra. La arquitectura marca la diferenciación de niveles y dimensiones de los espacios y la simbología pretende crear un ámbito de privacidad y misterio cuanto más se adentra en la estructura del monumento funerario.

La tumba constituye una barrera que separa la vida de la muerte, y que las protege una de la otra. Pero también es el lugar donde la vida y la muerte se encuentran. Por eso la tumba recurre a la inscripción y a la imagen con la que lo mira. Es un 'lugar de memoria' (...) Por medio de la imagen, el muerto exigía a los vivos que le otorgaran un lugar en sus recuerdos (Belting, 2007, p. 194, cursivas en el original)

Los ritos que hacían referencia al relato cosmogónico cumplían una función que por su vinculación con el mito resultaba ejemplificadora, pero tenían además una intencionalidad práctica precisa: el faraón debía registrar su misión sobre la tierra, reconociendo de esta manera el don divino con el que se lo había consagrado; por ello le correspondía conceder a los dioses un contra don que le asegurase su protección durante un largo período de reinado. En efecto, “(...) la tumba no es sólo un lugar de reposo, sino también el lugar de una acción” (Belting, 2007, p. 194). 
En este sentido, en el transcurso de la dinastía 18, la política expansionista del imperio egipcio incrementó la afluencia de tributos y la llegada de botín y cautivos procedentes del exterior, por lo que se amplió la capacidad de maniobra de los reyes e igualmente la de sus funcionarios encargados de administrar tales recursos.

El faraón pudo subrayar la posición de la familia real por la monumentalidad y riqueza de sus palacios y propiedades, demostrar su autoridad ideológica concediendo grandes donaciones a los principales templos y reforzar su poder político recompensando a los burócratas y oficiales leales (O’Connor, 1998, p. 260).

El faraón Akhenatón, frente al creciente poderío y autonomía del clero tebano administrador por antonomasia de los dominios-, se vio obligado a readaptar los modelos propios del sistema cosmogónico egipcio ${ }^{7}$ y para ello retornó a las bases mismas de conformación del estado y la sociedad egipcios, puntualizando su poder de control y regulación para concentrar las miradas en su capacidad exclusiva de dar y recibir.

\section{La visibilidad de las escenas de recompensa: la audiencia}

Si consideramos la espacialidad en el interior de una tumba rupestre, es lícito pensar que la decoración resultaba evocativa e indicativa de prácticas concretas, manifiestas. En consecuencia, era preciso hacerle saber a ese funcionariado ascendente que todas sus actividades y promociones se podían llevar a la práctica gracias al favor divino concentrado en la figura regia. Paradójicamente, el faraón no podía emprender sus obras sin la presencia y dirección del funcionario.

\begin{abstract}
El ritual -a través de sus diferentes componentes sonoros, visuales, corporales y teatrales- junto con los mitos y las representaciones simbólicas, expresan el corazón mismo de la actividad creativa humana. En ellos adquieren particular relieve diversas manifestaciones estéticas que varían de un lugar a otro y nos brindan claves para reconstruir e interpretar el contexto sociocultural. En efecto, estas manifestaciones se inscriben en procesos más amplios de construcción de identidad constituyendo vehículos de significados de la acción individual y colectiva. Tanto en condiciones de aislamiento como de interacción grupal, los rituales en sus diferentes variables contribuyen a la conformación y cambio de patrones estéticos establecidos, a la resignificación y actualización de tradiciones sociopolíticas (Wilde y Schamber, 2006, p. 63).
\end{abstract}

En la medida que la performance se define - parcialmente- como una acción predeterminada, aunque tiene sentido en el presente, es en los detalles donde se perciben las innovaciones. De este modo, interrelacionando entre sí los elementos de la comunicación, observamos que junto con la palabra oral está la escrita y la sonoridad, la luminosidad, los movimientos corporales que habilitan los espacios, los gestos, la circulación, lo visible y lo no presente (Hamui Sutton, 2010). Las particularidades de la audiencia - los interlocutores-, como la postura, el vestuario o el peinado, etc. aluden a rasgos culturales que también, ante la interpelación, nos "hablan". Entendemos, entonces, que hay palabras que en el momento en que se enuncian se convierten en acciones (Austin, 1998). Son actos de habla que transforman y cambian la realidad y, como indica Roland Barthes (1982), la textualidad (escritura-imagen) no es únicamente una operación de registro, sino una forma de hacer.

Siguiendo a Silvia Hamui Sutton (2010), entendemos que la presencia del otro, como parte de la performance, es imprescindible, ya que es a partir de la respuesta del "tú" que el "yo" reacciona y se motiva a corresponder el mensaje. Las expresiones visuales
7. Basándose en las excavaciones arqueológicas, Kemp analizó un primer intento reformista por parte de Amenofis IV- Akhenatón en la ciudad de Karnak, donde edificó una serie de templos y un palacio y llevó a cabo una celebración de la fiesta sed (Kemp, 1978). Análisis y revisiones posteriores se expusieron en Kemp (2013) y en Stevens, Dabbs, Shepperson y King Wetzel (2015). 
están contenidas en los mensajes no verbales; cada señal significa algo que se recibe o se transmite al otro, aunque muchas veces ésta sea inconsciente. Al detenernos en la gestualidad, como parte de la corporeidad, estamos implicando la interacción con los "otros", es decir, no es relevante sino en función de quién los "recibe". Al respecto, compartimos con Alfred Gell (2016) la propuesta de entender la "agencia" que atraviesa los procesos que circulan y se hacen perceptibles a través de las imágenes y, desde los aportes del "giro visual", "(...) cuando el ver se convierte en una nueva forma de hacer" (Bal, 2009, p. 328). La audiencia, en este sentido, es simultáneamente coautora del proceso de comunicación, aunque cada miembro percibe a su manera el evento (Shechner, 2000; Taylor y Fuentes, 2011). Hay un significado dialógico, socialmente construido y cambiante y no preformado o inmanente a la fuente visual (Bezerra de Menezes, 2003, p. 17).

$\mathrm{Al}$ respecto, en la tumba de Meryra I (TA 4), la escena en que se presenta a Meryra como funcionario distinguido frente al Templo de Atón permite entablar una relación con los títulos que portaba el funcionario porque era un alto sacerdote del Templo (Ver Figuras 1A y 1B).

Esta representación se ubica en la sala de las columnas, en el lado oeste de la pared suroeste y una de las escenas contiguas muestra a la familia real abandonando el palacio y dirigiéndose al templo con su escolta militar. Puede verse la síntesis de los dos pilares del estado egipcio: buena administración de los recursos y agradecimiento a la divinidad que hace posible su obtención. En este sector también se expuso la investidura de Meryra como alto sacerdote de Atón: la composición parece indicar que de los almacenes del templo se extraen los bienes a entregar en la ceremonia de recompensa. Esta escena se divide en dos grandes registros horizontales: en el extremo superior izquierdo se muestran los almacenes del templo y la cuidada simetría en la disposición de los bienes se extiende hacia el sector derecho de la escena para corresponderse con lo que parece ser la fachada del templo y el pronto ingreso de la familia real; en el extremo superior derecho se evidencia (a escala menor) el palacio y es notorio que los almacenes del palacio se corresponden con los planos en los que se hallan situados los carros con caballos que esperan para partir del templo tras la visita real. Hay delegados extranjeros que están presentando tributo en el templo y parte del mismo es luego trasladado al palacio. En el extremo inferior izquierdo se observan otras dependencias del templo (jardines, habitaciones, almacenes). En la pared oeste, la familia real abandona el palacio en carros, escoltada por los servidores y soldados. En el extremo inferior derecho se evidencian navíos aparcados y sus tripulantes haciendo reverencia; los barcos están cargados de bienes por lo que parecen representar la llegada de embarcaciones integrantes de una campaña o expedición al extranjero. Con tales bienes se colman los almacenes de templos y palacios. El disco solar que enmarca las escenas permite el ingreso de recursos al templo y con ello se solventa el palacio. Esa relación de doble dirección se explicita además en el ámbito de las relaciones sociales, más precisamente en la ceremonia de entrega de bienes de manos del rey.

Al analizar esta escena podemos acordar con la interpretación de Kemp (1976, p. 92 ss.), quien postula que la ceremonia de investidura sólo remite a la entrega de collares de oro mientras que en la de recompensa además de oro se entregan bienes de consumo. El texto refiere:

'Permite al Superintendente del Tesoro de los Anillos de Oro llevar (?) al Alto Sacerdote de Atón en Akhetatón, Meryra, para colocar oro en su cuello hasta la cima del mismo, y oro en sus pies, por causa de su obediencia a la doctrina del Faraón (ique viva, esté próspero y sano!), haciendo todo lo que estaba dicho en lo que concierne a estos espléndidos lugares, que el Faraón (ique viva, esté próspero y sano!) hizo en la Casa del Benben, en el templo de Atón, para el Atón 


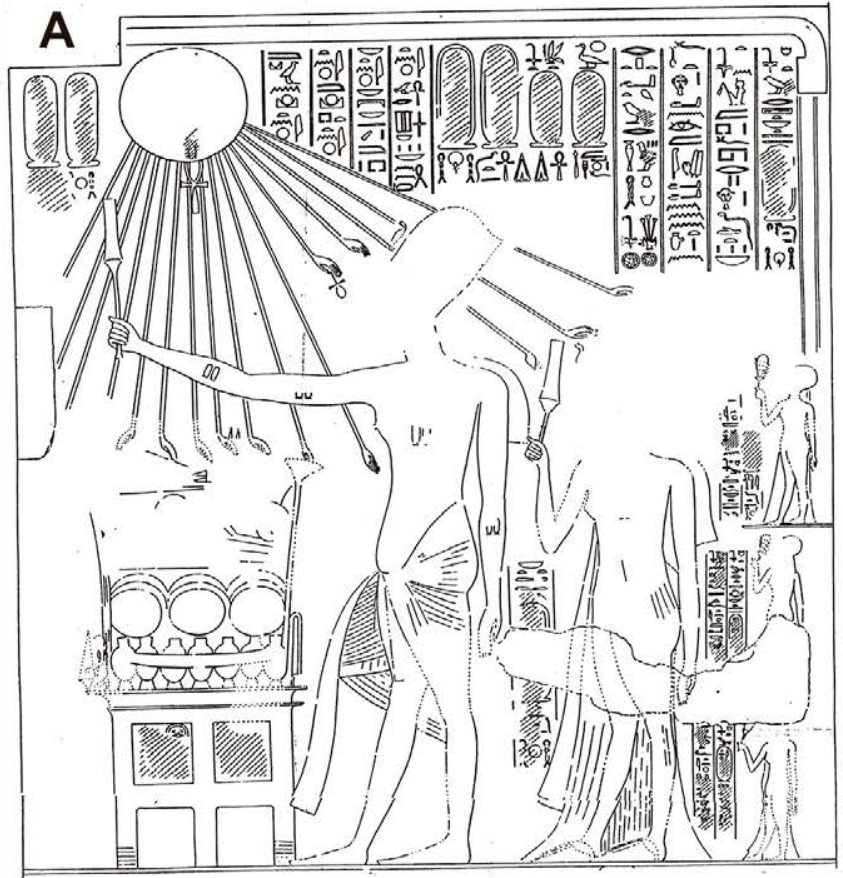

B

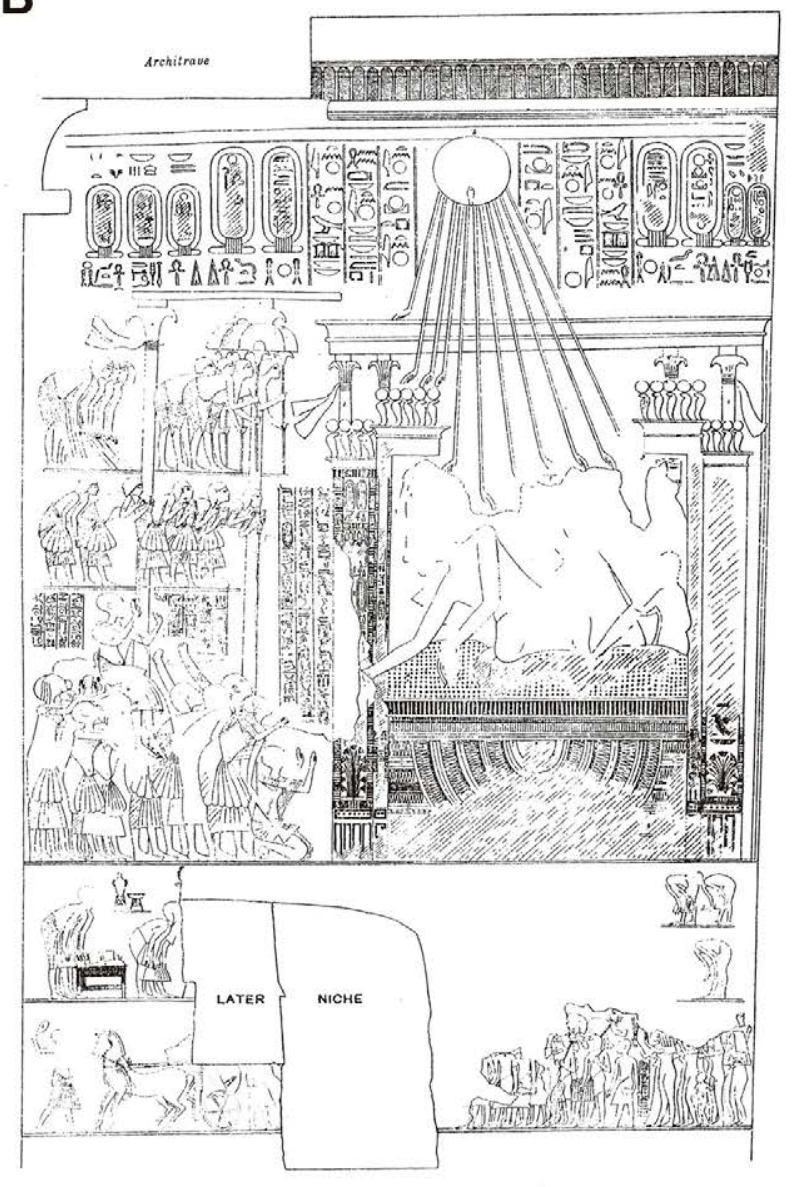

Figura 1. A) La familia real adora al disco solar en el templo. Escena de TA 4. (extraído de Davies 1903, vol. I, pl. XXVII); B) La recompensa a Meryra I. Escena de TA 4 (extraído de Davies 1903, vol. l, pl. Vl). 
en Akhetatón, cubierto con toda cosa buena, y con cebada y trigo en abundancia, 'La Mesa de Ofrendas de Atón' para el Atón'. (Davies, 1903, I, p. 36).

La expresión de esta escena en la sala transversal hablita la hipótesis del "mensaje propedéutico" para con los parientes y demás funcionarios que visitaran la tumba luego del entierro, quienes "ven" y "son vistos" como espectadores. La tumba opera en un plano psicológico (Kemp, 1992) y las escenas que la decoran exponen un contexto de sacralidad creado en torno a la figura del monarca; un dispositivo para mostrar al pueblo la conexión personal existente entre el faraón y Atón - el "trance admirativo" que refiere Posener (1960) — . La escena de dar recompensa y recibirla de manos del rey explicita el ideal monárquico, a la vez que recuerda que los altos funcionarios dependían de la capacidad de cooptación del rey y que sólo por su intermedio podían acceder a bienes de prestigio como son los collares de oro.

La escena que muestra a Panehesy (TA 6) condecorado por el rey se encuentra en la pared oeste del vestíbulo de su tumba y el marco de la ceremonia representada está dado por la ventana de aparición (ver Figura 2), ante la cual se muestran delegados extranjeros con vestimentas y rasgos característicos de asiáticos y nubios, escribas que registran el acontecimiento y contabilizan raciones, y diferentes objetos presentes. En este sentido, la contabilidad de los recursos y su exposición en un monumento funerario permite identificar la relación entre el orden cósmico y la performatividad en tanto acto presente del relato de origen (Ezzamel, 2009, 2012).

Panehesy es expuesto con sus collares de oro, en tanto el monarca entrega collares a funcionarios que actúan como los intermediarios. Los “testigos” tienen posturas que indican respeto y alabanzas ante la presencia del rey. En los registros inferiores los carros parten del palacio cargados con los bienes que el faraón entregó a Panehesy y los funcionarios exaltan al recompensado por el honor con el que ha sido distinguido.

Parennefer (TA 7) es otro de los casos a considerar respecto de la habilitación de la audiencia a través de las expresiones decorativas de su tumba (ver Figura 3). Las escenas que representan la entrega de la recompensa al funcionario están en la sala transversal, cubriendo la pared noroeste (Porter y Moss, 1968). Las escenas contiguas permiten "leer" lo acaecido en esa jornada festiva, por ejemplo la realización del banquete en la casa del homenajeado como un circuito redistributivo en el cual ahora Parennefer es el partícipe activo. Parennefer fue recompensado por el rey y la reina asomados a través de la ventana de aparición en el palacio. Debajo de la estructura que contiene la ventana se distingue el signo de la unificación de Egipto con sus plantas heráldicas enlazando prisioneros extranjeros. En los registros superiores se ubican los almacenes reales colmados de bienes acumulados, de un lado, y embajadores extranjeros, del otro. Se observa la recepción de la recompensa por parte del funcionario y la distribución de los bienes a manos de sus sirvientes. Los carros se aprontan a salir del recinto llevando los bienes recibidos: raciones representadas como sacos con granos, jarras de cerveza, diversas ánforas y collares de oro.

En el caso de la tumba del funcionario Tutu (TA 8), las escenas que relatan el acto de concesión de bienes al noble están localizadas en la pared oeste de la sala hipóstila. El difunto es recompensado por el rey y la reina en la ventana del palacio y asisten a la ceremonia los embajadores extranjeros, otros oficiales y servidores. En el registro inferior se ve al difunto escoltado hacia su casa por sus amigos y parientes (ver Figura 4).

En relación con el desempeño funcionarial, Ay y su esposa (TA 25) fueron recompensados por el rey en la ventana de aparición, donde también se halla la familia real obsequiando collares de oro al funcionario y su esposa (ver Figura 5). Se observan los carros apostados esperando cargar las raciones entregadas como recompensa, los delegados extranjeros 


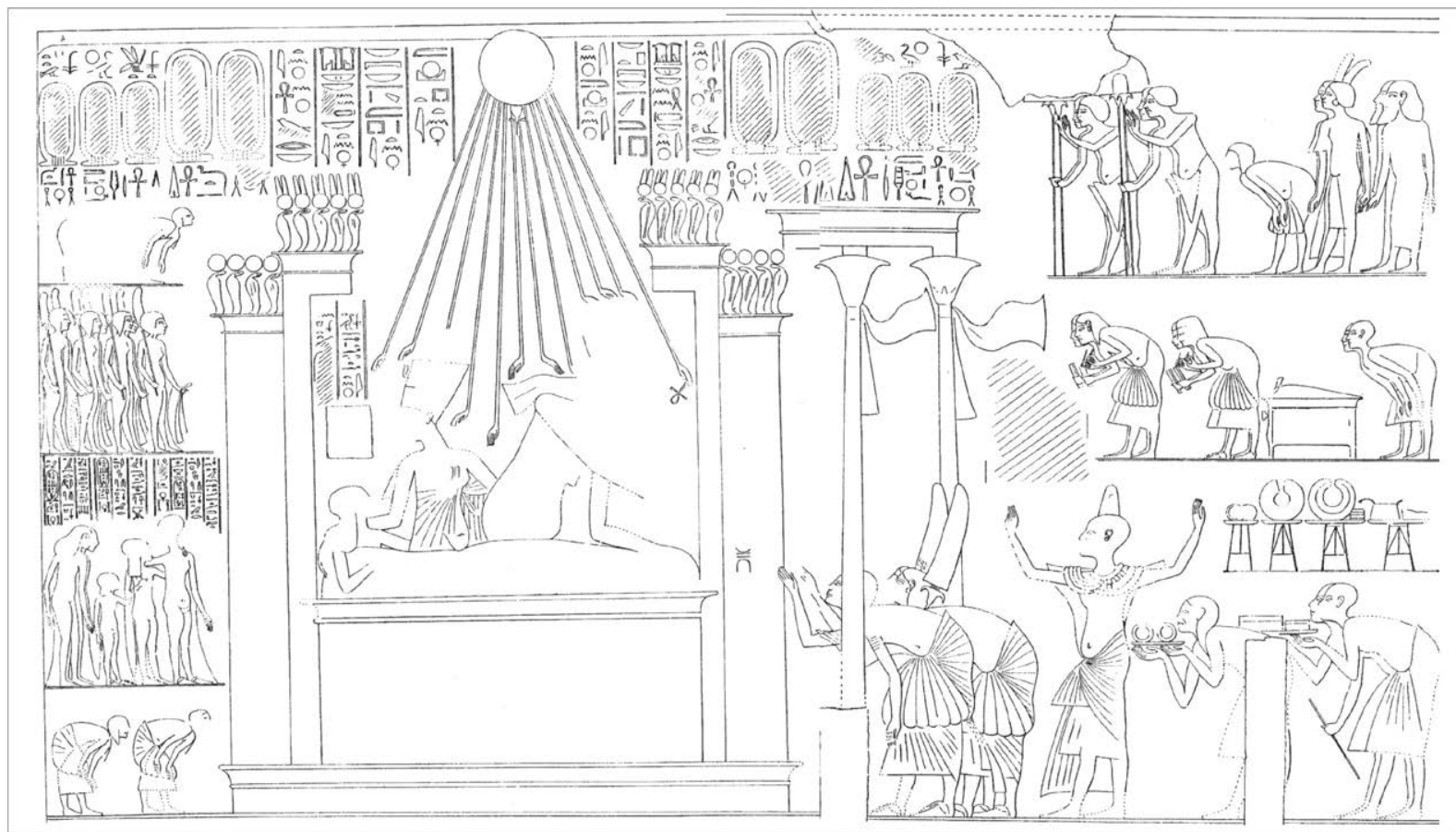

Figura 2. Recompensa de Panehesy procedente de TA 6 (extraído de Davies 1905, vol. II, pl. XI).

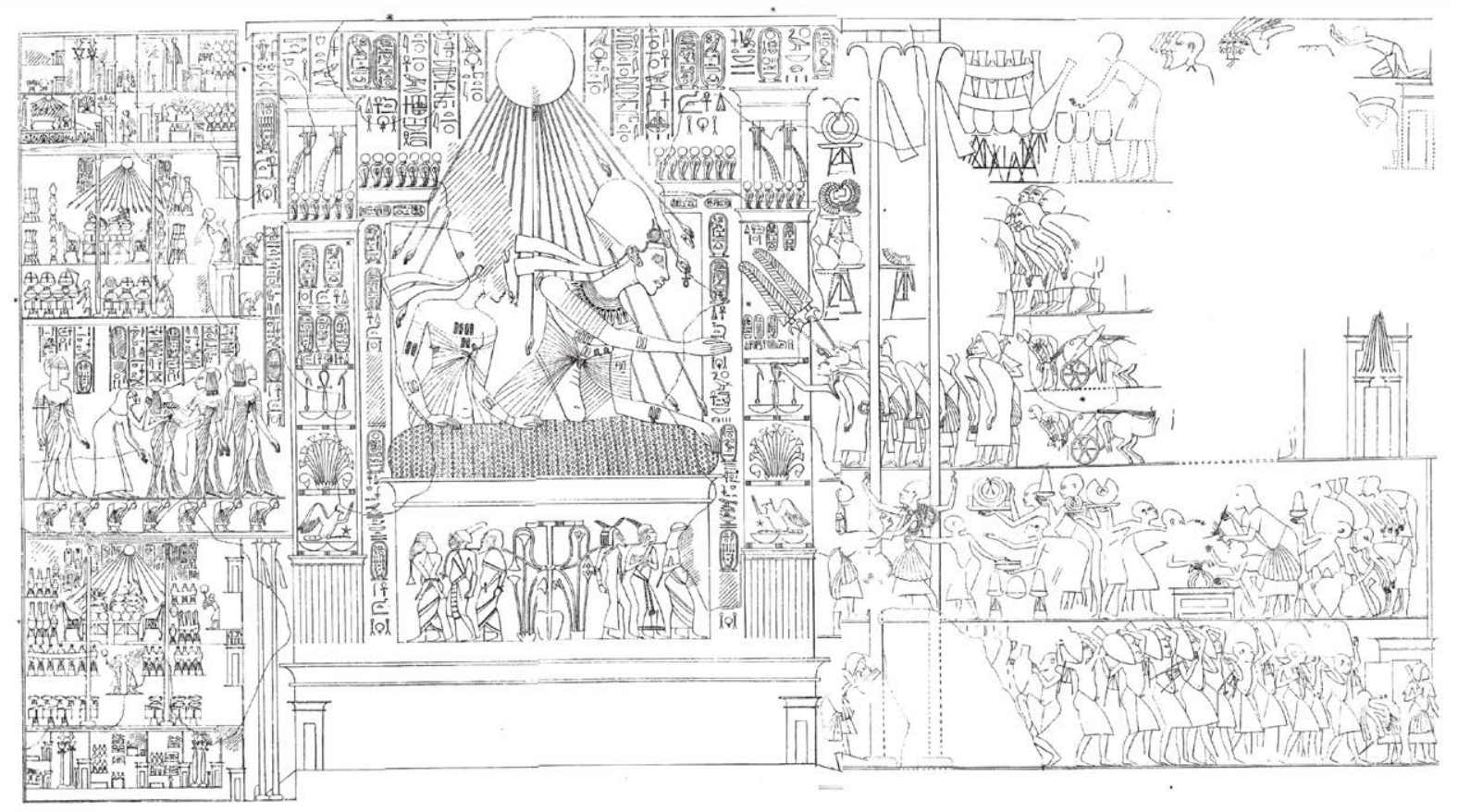

Figura 3. Recompensa de Parennefer procedente de TA 7 (Extraído de Davies 1908, vol. VI, pl. IV).

posicionados en los registros cercanos a la figura del monarca, mensajeros que portan en sus manos rollos de papiro, escribas que inspeccionan, asientan lo acontecido y contabilizan los bienes, portadores de abanicos y de estandartes como escoltas del rey. En el registro inferior, Ay es aclamado por sus pares afuera del palacio. Los postigos cerrados de la ventana marcan el fin de la ceremonia de recompensa, el funcionario se 


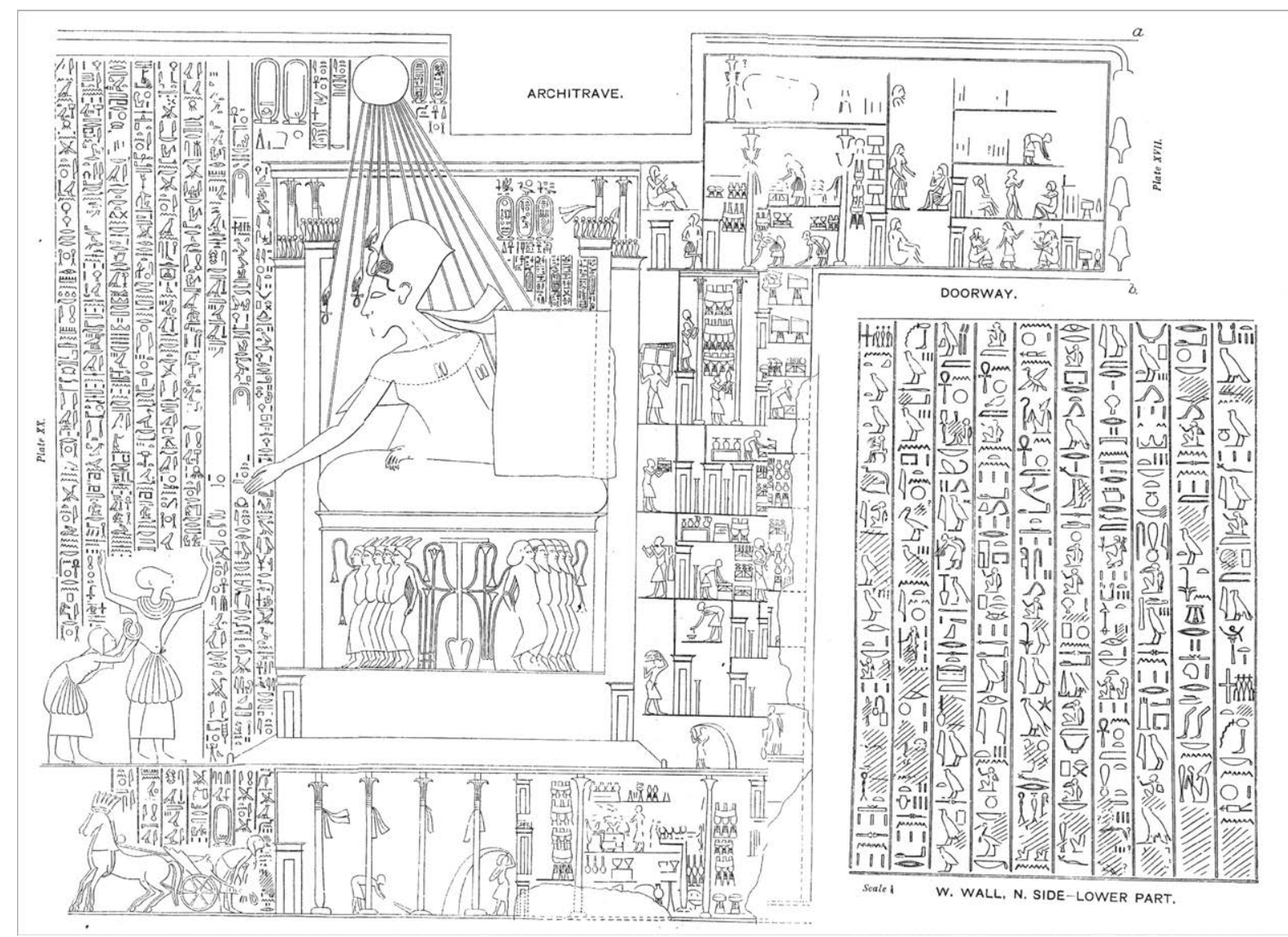

Figura 4. Recompensa de Tutu. Escena de TA 8 (extraído de Davies 1908, vol. VI, pl. XIX).

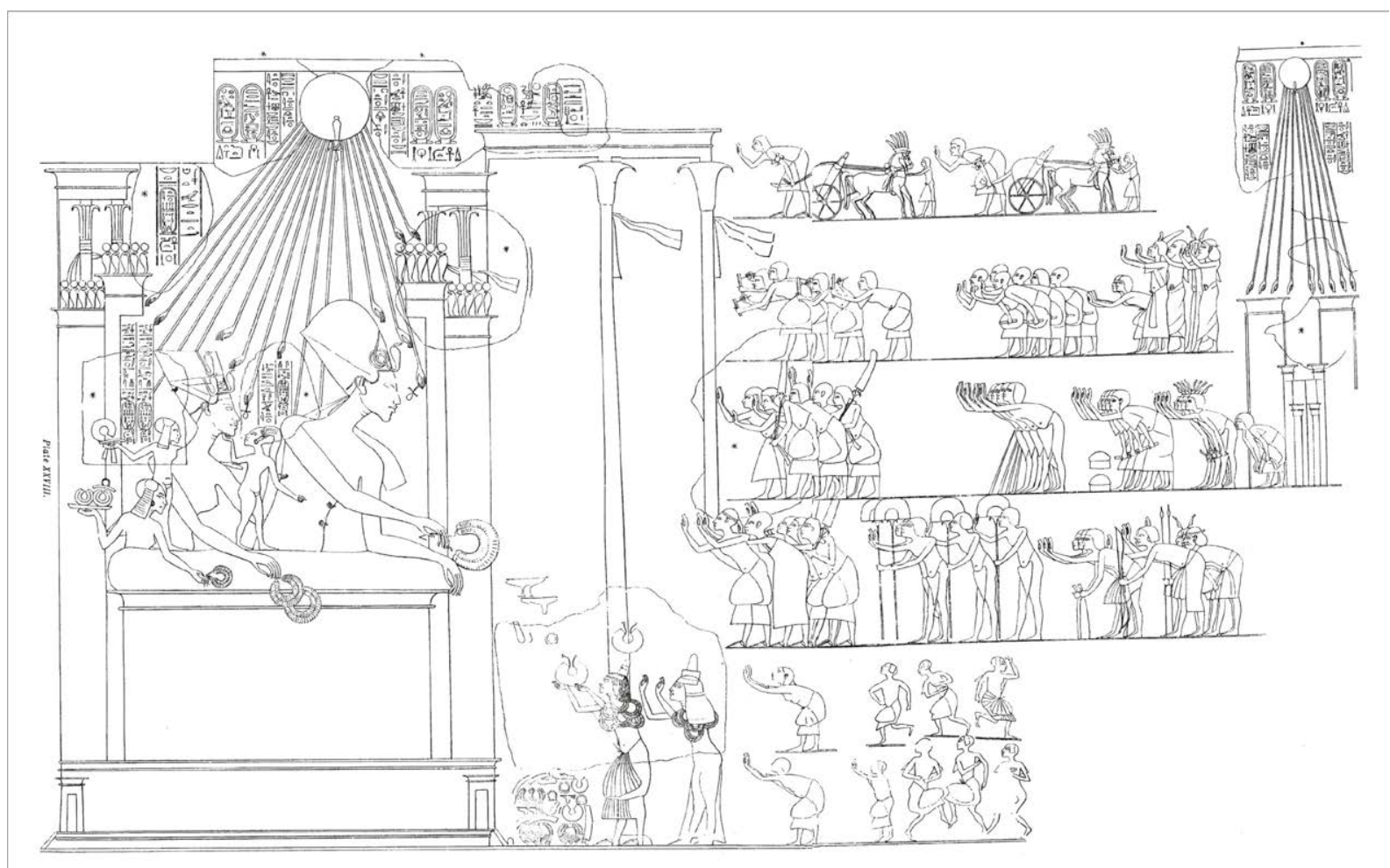

Figura 5. Recompensa de Ay y su esposa. Escena de TA 25 (extraído de Davies 1908, vol. VI, pl. XXIX). 
muestra orgulloso ante sus pares quienes lo reverencian y felicitan. Finalmente, la noticia es transmitida a la guardia y ésta comenta la ceremonia de la que fueron partícipes Ay y su esposa.

Las recompensas a los funcionarios leales dan cuenta de la conformación de una nueva elite burocrática imperial. En el caso de Huya (TA 1) (ver Figuras 6A y 6B), quien era supervisor del harén real y supervisor del tesoro - entre otros títulos y epítetos-, expuso en su tumba dos escenas de recompensa, ambas en la sala transversal.

Las escenas constituyen un relato y su visualización opera en un sentido ejemplificador. Todas se encuentran concatenadas y se enlazan entre sí permitiendo conocer el fundamento y el correlato de un determinado evento.

En TA 2, una de ellas muestra a la familia real recibiendo los tributos de las tierras extranjeras sometidas (Ver Figura 7). Los tributos nubio, asiático, libio, diferentes cortesanos, hombres con bouquets, soldados, toros, y demás bienes, son registrados de la siguiente manera:

Año [12, segundo mes de la estación del invierno, octavo día] del Rey del Alto y Bajo Egipto, que vive de la Verdad, Señor de las Dos Tierras, Akhenatón, grande en su (tiempo de) y la gran esposa del Rey, su amada, Nefertiti, que viva por siempre y para siempre. Su Majestad aparece sobre el trono del Padre Divino y Soberano; el Atón, quien vive en la Verdad; y los jefes de todas las tierras traen el tributo [...] suplicando el favor para su tierra (?) para inhalar el aliento de vida. (Davies, 1905, II, p. 38).

En forma contigua se representó la ceremonia de la recompensa al funcionario (ver Figura 8), que es posible gracias al acopio de bienes que han ingresado al palacio desde el exterior. Luego, en la misma ubicación pero del lado este, en la pared norte, el difunto luce sus collares y premios y en la siguiente se ve a parte de la familia real en su visita al Templo de Atón, interactuando con el propietario de la tumba. Así se muestra que religión y economía, con una buena administración y un ajustado control, permiten sostener el imperio y, consecuentemente, recompensar a los funcionarios leales. Como el difunto ha actuado correctamente durante su vida terrenal y ha obedecido el mandato divino y a la vez regio, puede tener una vida perpetua acorde y acompañar a su monarca por toda la eternidad.

Nos hemos propuesto interpretar los íconos que reconocemos como habilitantes de la indicación performativa, a saber: funcionarios del templo, del palacio, militares, delegaciones extranjeras y familia real. La representación de quienes hacen el acto ritual dispone las actuaciones futuras y, en un entorno funerario, expresan su vinculación con los rituales de ofrenda (Stevens, Dabbs, Shepperson y King Wetzel, 2015). Es la interacción social la que produce significados, movilizándose diferencialmente en tiempo, espacio, lugares y circunstancias sociales. Los agentes que intervienen y ciertos atributos que ostentan resultan imperiosos para dar existencia social (sensorial) a sentidos y valores, hacerlos actuar (Bezerra de Menezes, 2003).

\section{Ver y ser visto: acerca de la importancia de pertenecer}

Según Ulpiano Toledo Bezerra de Menezes (2003), es necesario tomar la imagen como una declaración, que sólo se aprehende en el habla, en una situación. Al estudiar la epigrafía funeraria, puede deducirse el impacto psicológico que debería haber implicado el hecho de ser uno de los elegidos para participar de la ceremonia de entrega de la recompensa a manos del rey y, una vez expuesta en la tumba, estar habilitado a admirarla. 

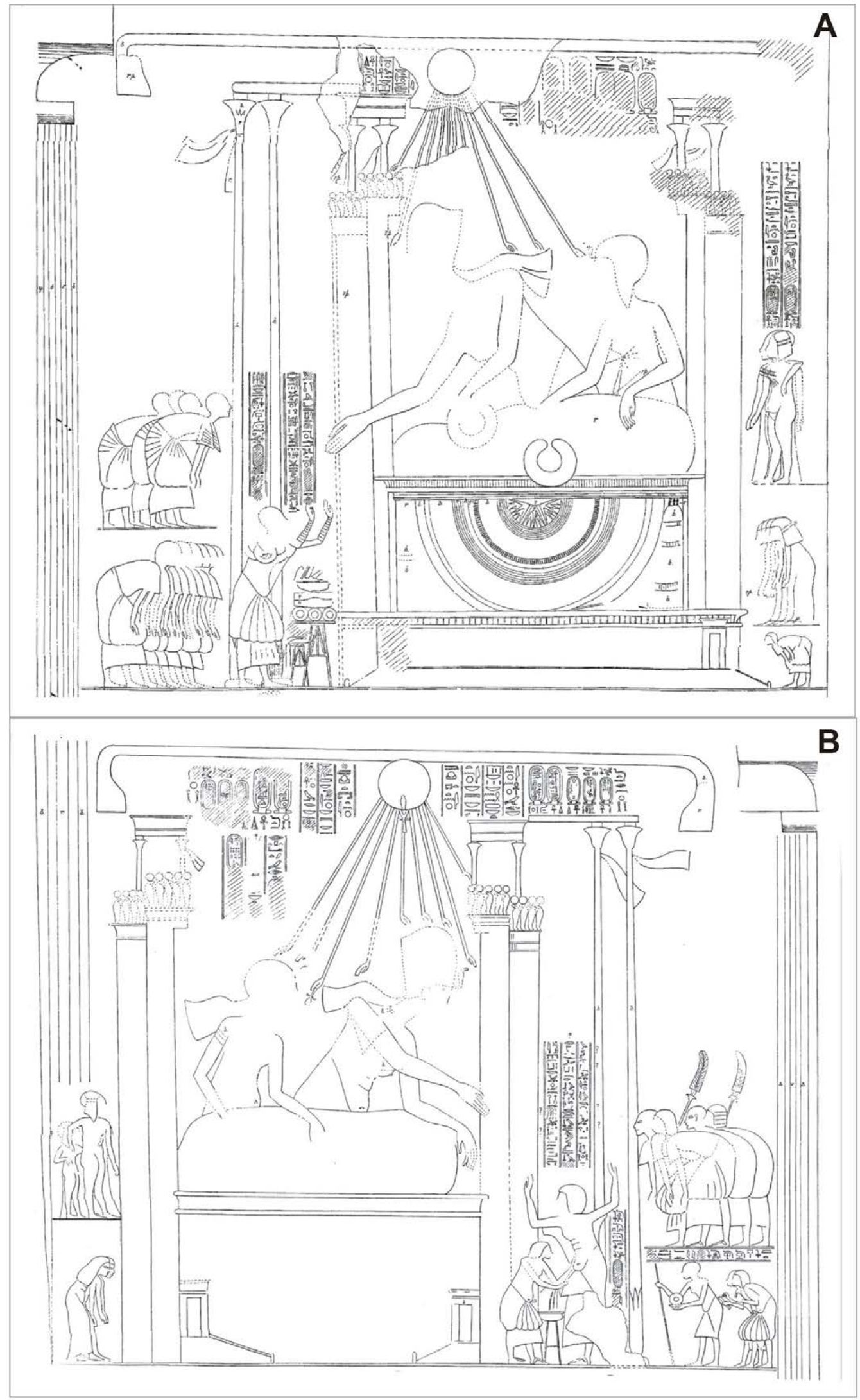

Figura 6. A) Recompensas de Huya. Escenas de TA1 (extraído de Davies 1905, vol. III, pl. XVI); B) Recompensas de Huya. Escenas de TA1 (extraído de Davies 1905, vol. III, pl. XVII). 


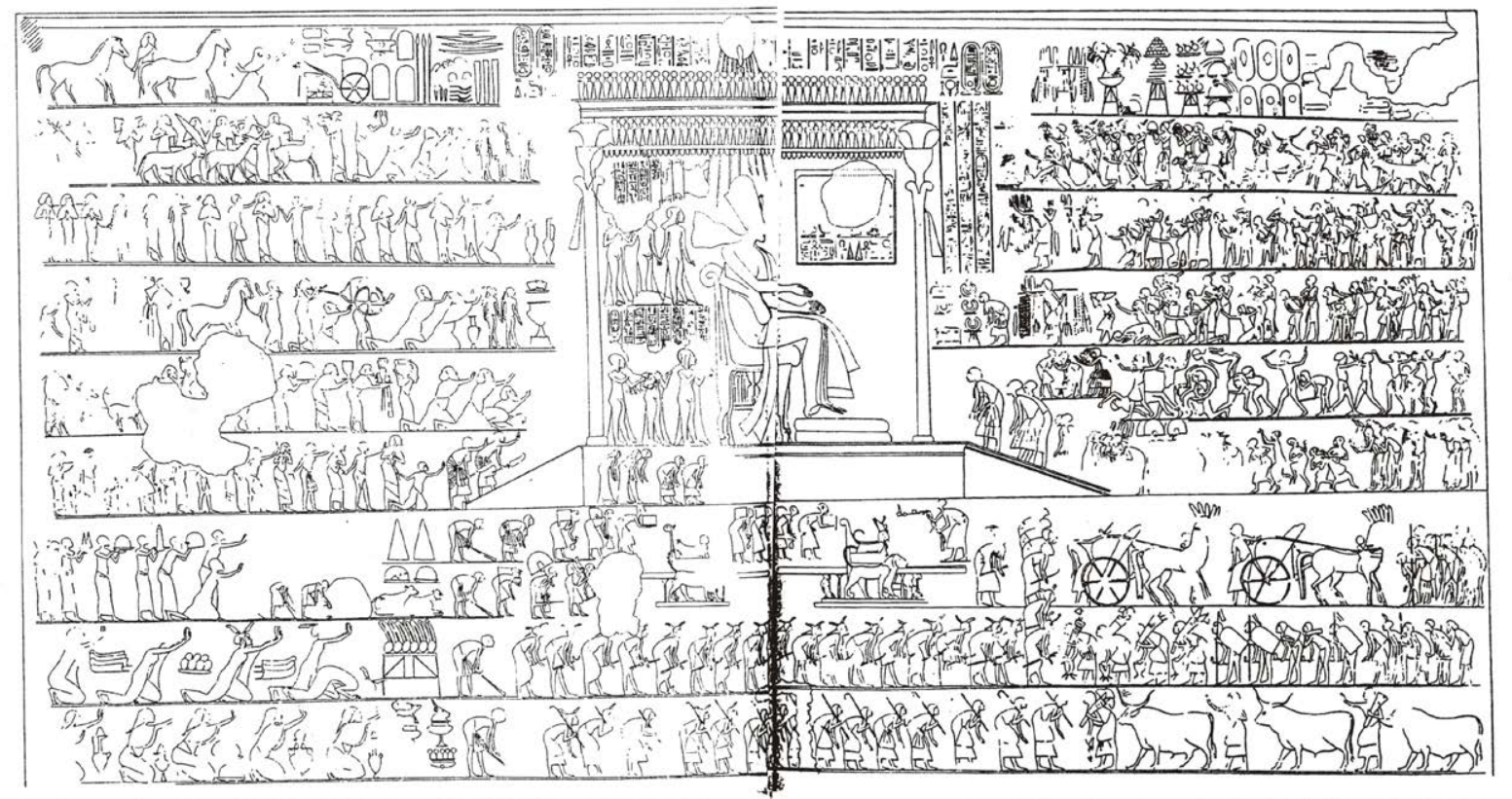

Figura 7. Presentación del tributo de las tierras extranjeras. Escena de TA 2 (extraído de Davies 1905, vol. II, pl. XXXVII).

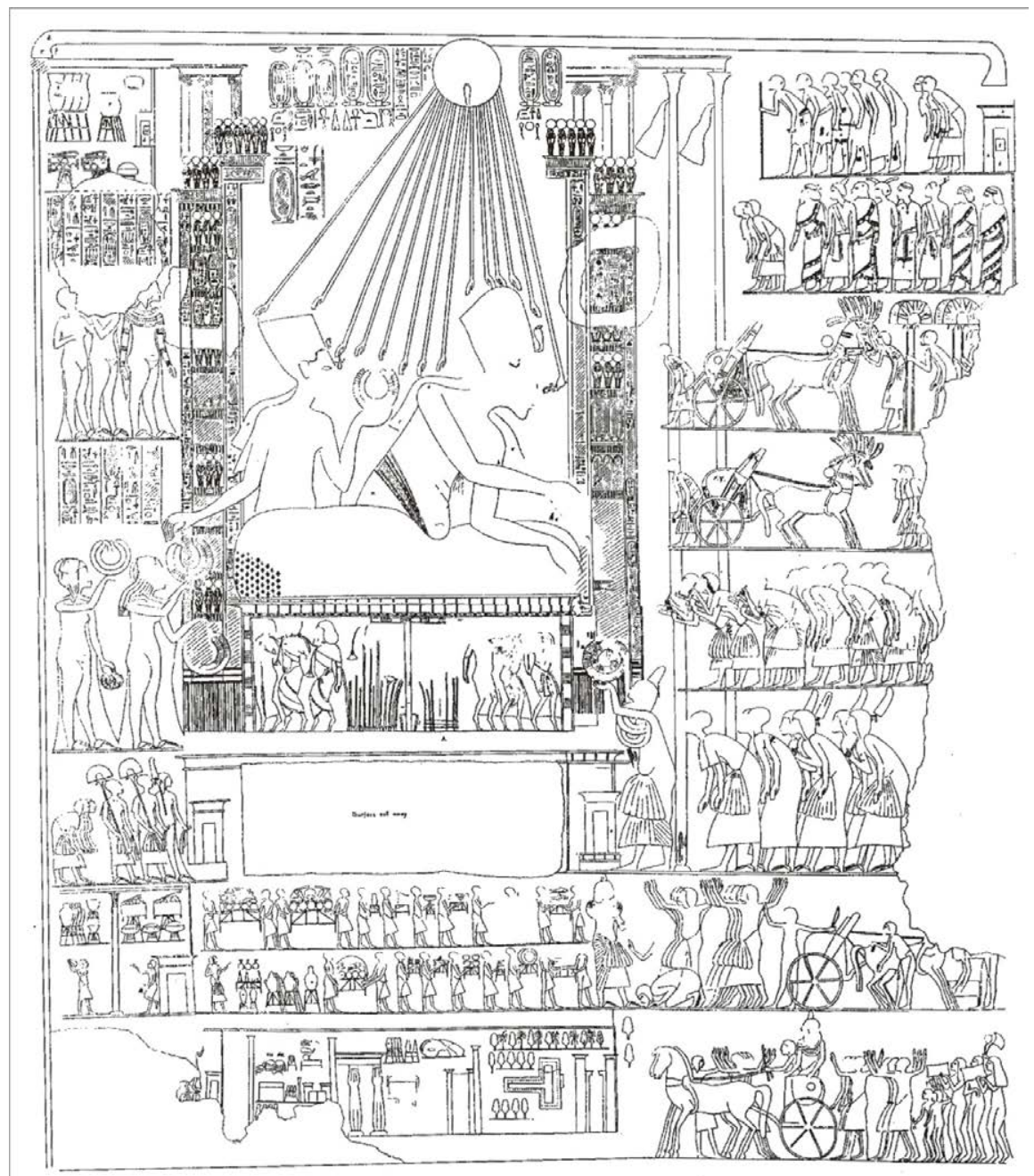

Figura 8. Recompensa de Meryra II. Escena de TA 2 (extraído de Davies 1905, vol. II, pl. XXXIII). 
El desarrollo iconográfico ofrece en cierto sentido un espectáculo pero teñido justamente de exclusión, de acuerdo con Baines (2006). Justamente, sólo los funcionarios más leales y allegados al monarca podían protagonizar la escena, ante la vista no sólo de los habitantes de la ciudad sino también de delegados y funcionarios extranjeros que asistían a la ceremonia (Kemp, 1976).

Cada época buscó un escenario teatral para este gran momento, construido alrededor de ciertos elementos básicos: un amplio espacio descubierto, un lugar elevado donde se pudiera ver al rey dentro de un marco oficial y un pabellón en el que podía vestirse y descansar cómodamente y en privado (Kemp, 1992, p. 77).

En este sentido, tanto el contenido de los propios relatos como la representación de los mismos creaban ámbitos de coparticipación, a través de los actos rituales indicados. La tumba constituía un reservorio de memoria e historia.

El núcleo de la celebración, en apariencia una "inofensiva ceremonia" como la llama Redford (1976, p. 124), es la prodigalidad del soberano, su capacidad de dar — previa obtención- mediante la recepción de tributos de los pueblos sometidos. Toda la composición gira en torno a la capacidad redistributiva del monarca pues se presentan las imágenes de manera grandilocuente. Ello posibilita la entrega de bienes de manos del monarca, ordena, ejemplifica y disciplina. En TA 8 se registró: 'Salud a Nefer-kheperura, el Atón [quien establece] la humanidad y los convierte en generaciones!”' (Davies, 1908, VI, p. 12), asimismo:

Dicho por los grandes, los compañeros, 'Cuán admirables son tus proyectos, Neferkheperu-ra. Cuán próspero es él quien está en tu (?) [...] ¡Oh justo hijo de Atón! Tú traes generaciones a la vida. Tú eres para la eternidad como el Atón' (Davies, 1908, VI, p. 13).

Y, además: “[...] hermoso como Atón quien les da vida, Nefer-kheperu-ra, quien crea a la humanidad y da existencia a las generaciones. Él es permanente como el cielo en el que está Atón."' (Davies, 1908, VI, p. 13).

Antes de Amarna las recompensas eran estipuladas de acuerdo con servicios efectivos prestados por el dignatario. Bajo el reinado de Akhenatón, en cambio, la recompensa no se justifica más que por la lealtad. Esto quiere decir que no equivale a un desempeño notorio o a la realización de una actividad trascendental sino, por el contrario, al hecho de ser funcionario en Akhetatón. En TA 4 se expuso: "El buen gobernante, poderoso en su establecimiento, resplandeciente como (?) el Atón” (...) (Davies, 1905, III, p. 13). En TA 8:

El faraón (ique viva, sea próspero y sano!) [...] capitanes de los arqueros (?), supervisores de los caballos, supervisores de [campaña?] [...] cada Servidor de Atón del Atón [...] en toda la tierra, hombres [...] faraón, mi (?) [señor, (por las) órdenes que tú das] (tienen) grandes riquezas (?), las recompensas de Nefer-kheperu-ra, a sus sirvientes quienes escuchan su buena enseñanza de verdadera vida, las riquezas que él (?) [me ?] da en la forma de un impuesto (?) en [...] para distinguirme por los favores más que a ningún (otro) favorito suyo. (Davies, 1908, Vl, pp. 11-12).

La lealtad al decidir adherir a la reforma también se expresa en TA 25, por ejemplo:

Yo era leal al rey quien me acogió, meticuloso para con el Señor de las Dos Tierras, servicial a su señor. Yo seguí el espíritu de Su Majestad como su favorito, admirando su belleza cuando él aparece en su palacio. Yo era cabeza de los grandes, los compañeros del Rey, jefe de todos aquellos que siguen a Su Majestad [...] Él puso Verdad en mis partes internas; la falsedad era mi abominación; yo sé que Ua-en- 
ra, mi señor, se regocija con ello, siendo él prudente como Atón y verdaderamente comprensivo. El multiplicó para mí mis recompensas de plata y oro. Yo era jefe de los grandes, cabeza de los rekhyt. Mis logros y mi carácter excelente (posibilitaron) mi presente posición. (Davies, 1908, VI, p. 28).

El círculo redistributivo se expone una y otra vez en las tumbas privadas y los partícipes de estos mecanismos de cooptación y distribución están claramente manifestados; en TA 1, por ejemplo:

Año 12, el segundo mes del invierno, el octavo día. Vida para el Padre, el doble Jefe, Ra-Atón, quien da vida por siempre y para siempre! El Rey del Sur y Norte Neferkheperu-ra y la Reina Nefertiti, vivan por siempre y para siempre, hacen una aparición pública sobre el gran palanquín de oro para recibir el tributo de Siria (Kharu) y Etiopía (Kush), el Oeste y el Este (Siria y Etiopía significan el Norte y el Sur); todos los países lo recolectaron al unísono, y los isleños del medio del mar, traen ofrendas al Rey (cuando él está) sobre el gran trono de Akhetatón para recibir los impuestos de toda tierra, garantizando para ellos el soplo de la vida." (Davies, 1905, III, p. 9).

Se expresa así la síntesis del estado. El disco solar como divinidad imperial con su poder simbólico, el faraón con su poder tangible, los extranjeros sometidos y su obligación de enviar los recursos estipulados como tributos para el estado central y, finalmente, el funcionario. Éste es el articulador inmediato de todos estos elementos ya que es quien posibilita, en última instancia, que efectivamente se realicen las obras, se contabilicen los tributos, se transporten las ofrendas, etc.

Si nos detenemos, por ejemplo, en la mirada, se evidencia que es necesario el "otro" para que lo que comunique tenga significado. En tal sentido, el contexto tiene que ser adecuado para que sea efectiva la comunicación; por ello, aunque no se cuestionen, las características espaciales son importantes para la intersubjetividad (Hamui Sutton, 2010).

El momento festivo de la ceremonia (luego de que cuidadosamente se ha registrado el egreso de los bienes de los almacenes) se indica a través de la presencia de bailarines, cantantes y acróbatas, como se observa en la tumba de Ay (Figura 5). En medio de esta algarabía el artista debió representar al pueblo egipcio y lo hizo mostrando al funcionario en su camino de regreso a su casa, atravesando el camino real en su carro y siendo saludado y vitoreado por hombres, mujeres y niños, lo que se ve en las tumbas de Ay (Figura 5), Panehesy (Figura 2), Tutu (Figura 4), Meryra I (Figura 1B) y Meryra II (Figura 8). La guardia real, encargada de asegurar el desarrollo ordenado de la ceremonia, también fue representada como articuladora de los espacios público y privado. Por caso, un breve diálogo entre un soldado y un transeúnte expuesto en TA 25, en la escena de la ceremonia de recompensa, enuncia: “¡Apresúrate!, el griterío; mira acerca del bullicio; quiero saber quién es y regresa rápido!” (Davies, 1908, VI, p. 23). Otro soldado pregunta a un niño que evidentemente ha asistido a la ceremonia:

¿Por quién están ellos gritando?”, a lo que éste responde: “Ponte de pie y podrás ver: esta es la ocasión en la cual el Faraón (que viva, esté próspero y sano!) entrega dones para Ay, el padre del dios y Tiy! El Faraón (que viva, esté próspero y sano!), ha dado para ellos millones de cargas de oro y todo tipo de riquezas! (Davies, 1908, VI, p. 23).

Atentos a la performatividad en tanto acto para dar cuenta de la capacidad del lenguaje para construir la realidad social (Austin, 1998), asumimos que el discurso, los discursos, producen lo que nombran, por su necesaria vinculación con la acción. El efecto "positivo" que tenía el mensaje regio se verifica en los epítetos pronunciados ante su persona por los funcionarios de la administración. La expresión de la ceremonia de entrega de las recompensas denota un significado de carácter público, acentuado por la presencia 
de delegados extranjeros, funcionarios burócratas y militares, cautivos extranjeros, sirvientes, etc., que se ubican en la escena como "testigos oculares" (Posener, 1960), necesarios y constitutivos (Schulman, 1988) de la ritualización. Los textos que integran las escenas dan a entender que no había "pretexto" para recompensar al funcionario o aún más, que éste merecía ser reconocido por el sólo hecho de sus funciones. Tal es el caso de Meryra, quien fue recompensado por su obediencia y lealtad al nuevo régimen, de acuerdo con lo registrado por los escribas (Figura 1B), a saber:

Lo dicho por el Rey del Alto y el Bajo Egipto, que vive de la verdad, Señor de las dos Tierras, Nefer-kheperu-ra-Ua-en-ra. 'Deja al Superintendente del Tesoro de los Anillos de Oro (que) presente al Alto Sacerdote de Atón en Akhetatón, Meryra, y coloque oro en todo su cuello, y oro en su pie, a causa de su obediencia a la doctrina del Faraón (que viva, sea próspero y sano!) (Davies, 1903, l, p. 36).

Otro ejemplo es el de Tutu (Figura 4), en cuya tumba se expone lo siguiente: "El Chambelán (ami-khent), Tutu, maakheru, dice 'Escucha lo pronunciado por tu hijo, Ua-en-ra, ¡oh Atón, quien lo formó y colocó a perpetuidad!" (Davies, 1908, VI, p. 10).

El discurso del Rey del Sur [y Norte] de Egipto, que vive de la Verdad, señor de las Dos Tierras, Nefer-kheperu-ra-Ua-en-ra. 'Los [grandes] y cabezas de compañía quienes están (de pie) ante el faraón (que viva, sea próspero y sano!) Mi propósito es conferir una recompensa excepcional equivalente a miles (?) [de lo que es dado] a los hombres. Él no ha oído que haya sido favorecido, pero Yo (?) doy (dones) para el Chambelán, Tutu, a causa de su amor al Faraón, que viva, sea próspero y sano, su Señor. (Davies, 1908, VI, p. 11).

En la atmósfera de exclusividad —en relación con los componentes figurativos y con los espectadores- que se expuso en las tumbas privadas (Baines, 2007), la inclusión de la audiencia en la representación de la ceremonia de entrega de las recompensas a los nobles posibilitó la exhibición de los distintos sectores de la sociedad egipcia y extranjera con el objeto de asegurar el orden cósmico a través de las estrategias adoptadas por el faraón para mantener maat y asegurar la pervivencia del orden ante el caos.

En TA 25 la admiración tras la recompensa se expuso de la siguiente manera: (un centinela pregunta): "Para quién se ha realizado esta celebración, mi niño?" (el responde): "La celebración se ha realizado para Ay, el padre del dios, junto con Tiy . Ellos han sido hechos gente de oro!" (Davies, 1908, VI, p. 23).

La sociedad asistía perpleja a las escenificaciones del poder real centradas en las ceremonias públicas realizadas en el palacio y el templo, pero únicamente una pequeña porción de la misma podía acceder en forma directa al favor regio. El culto solar era privilegio del faraón y de su familia, ya que lo notorio es la integración de la familia real a la ejecución del culto, si bien el Atón se presentaba a la vista de todos en cada amanecer y podía ser reverenciado con sólo mirar al cielo.

\section{Reflexiones finales}

Las fiestas, específicamente los rituales que las componen, cumplen la función de recrear y renovar la base de sustentación sobre la que se asienta el aparato estatal. La explicitación de las recompensas al funcionariado adepto al nuevo régimen estipulaba el reconocimiento del papel social y político de los súbditos: los contactos se establecen entre el rey, quien se presenta como dador por excelencia y una parte selecta de la sociedad representada en actitud pasiva y meramente receptora, consagrada por el favor real. La manifestación del poder de captación de recursos se tornaba necesaria teniendo en 
cuenta el objetivo monárquico que consistía en el reposicionamiento de la monarquía y del papel del faraón. La ceremonia de recompensa, entonces, tenía la función elemental de realimentar el sistema autocrático de gobierno: la nobleza era recompensada por el rey, quien a su vez reconocía la necesidad que tiene de ser legitimado para asegurar la permanencia del poder real.

La importancia del flujo circular de intercambios de bienes y favores hizo que en el período amarniano fuera plásticamente expresado por medio de la decoración de las tumbas privadas. El momento de dar y recibir se instituye en el seno de cada ceremonia y promueve el acto ritual: la entrega de bienes a los funcionarios como una recompensa por parte del rey constituía un reconocimiento del buen desempeño en las actividades, tanto en el nivel local como en el extranjero.

La capacidad de captación y apropiación de recursos - materiales y simbólicos- del estado, debía ser expuesta a quienes sustentaban el sistema, logrando de este modo reafirmar la autoridad real; el faraón representaba la cúspide del sistema social y el eje del aparato estatal. En este sentido, las prácticas reciprocitarias caracterizaron la relación dicotómica entre monarquía y nobleza, contribuyendo a la armonía universal. En tanto que el orden terrenal debía ser controlado para evitar el advenimiento del desorden, el rey requería para su sostén del funcionariado, al que retribuía sus servicios. Así, el mensaje disciplinador ha sido convenientemente enviado a cada uno de los estratos sociales y el acto performativo ha adquirido significado.

Las ceremonias expresan una interacción entre los sujetos sociales que las constituyen, sus “protagonistas". La ceremonia de donación de recompensas presenta "códigos de interacción" (Skorupski, 1985) entre sus componentes sociales que se muestran en posturas de alabanza para con el monarca y su acción de tipo divina (ademanes de deferencia: posición reverencial, de tipo penitente, genuflexa, arrodillados y besando los pies del homenajeado tras su reconocimiento real). Según Skorupski (1985), el objetivo de la conducta del "código de interacción" es mantener o establecer un equilibrio, un acuerdo mutuo, entre las personas involucradas en una interacción en lo que respecta a sus roles o categorías y a sus compromisos y obligaciones recíprocos. Consiste en actitudes (señas que significan respeto y reconocimiento); expresiones (gestos de alegría, de atención, de subordinación, miradas de reconocimiento y admiración); posturas y grados de proximidad corporal. Así, el status social de los sujetos se define por su proximidad al monarca en la ceremonia de entrega de las recompensas en la ventana del palacio.

A partir de las escenas presentadas, analizamos la ceremonia de entrega de la recompensa integrada por raciones de alimentos y por collares y brazaletes de oro, además de oro en discos (en bruto, en su mayoría procedente de las tierras nubias). La iconografía funeraria muestra una composición circular: 1) el monarca, a través de la gracia divina, domina los territorios extranjeros; 2) sus recursos tanto humanos como materiales se concentran ahora en el estado egipcio encabezado por el faraón y 3) éste, como reconocimiento al desempeño de la burocracia ( sistema de delegación del poder), entrega al funcionario parte de los bienes recibidos. La circularidad del sistema está de nuevo asegurada, manteniendo satisfechos a los potenciales competidores.

\section{Agradecimientos}

Deseo expresar mi agradecimiento a la Secretaría de Ciencia y Tecnología de la Facultad de Filosofía y Humanidades, Universidad Nacional de Córdoba, cuyo financiamiento hizo posible el desarrollo de la investigación que se sintetiza en este artículo. Asimismo, 
manifiesto mi reconocimiento a la Dra. Liliana Manzi y a la Dra. Andrea Zingarelli por sus comentarios y aportes para la consecución del manuscrito. Por último, expreso mi gratitud para con los evaluadores, quienes indudablemente enriquecieron el contenido del artículo con sus sugerencias y observaciones, convocando a la pregunta y la reflexión y contribuyendo a la construcción del artículo respetando el sentido argumental del mismo. 


\section{Deferencias citadas}

》Alvarado, M. (2006). Paratexto. Buenos Aires: EUDEBA.

»Austin, J. L. (1998). Cómo hacer cosas con las palabras. Barcelona: Paidós.

» Badawi, A. (1966). Architecture in Ancient Egypt and the Near East. Cambridge, Massachusetts and London: The M.I.T. Press, Massachusetts, Institute of Technology.

» Baines, J. (2006). Public Ceremonial Performance in Ancient Egypt: exclusion and integration. En T. Inomata y L. S. Coben (Eds.), Archeology of Performance: Theaters of Power, Community, and Politics (pp. 261-302). Oxford: Oxford University Press.

» Baines, J. (2007). Visual and Written Culture in Ancient Egypt. Oxford: Oxford University Press.

» Bal, M. (2009). Conceptos viajeros en humanidades. Murcia: Cendeac.

» Barthes, R. (1982). Lo obvio y lo obtuso. Imágenes, gestos, voces. Barcelona: Paidós.

» Belting, H. (2007). Antropología de la imagen. Madrid: Katz editores.

» Bezerra de Meneses, U. T. (2003). Fontes visuais, cultura visual, História visual. Balanço provisório, propostas cautelares. Revista Brasileira de História, 23(45), 11-36.

»Davies, N. de G. (1903-1908). The Rock Tombs of El Amarna (6 vols.). Archaeological Survey of Egypt, Memoirs 13-18. London: Egypt Exploration Fund.

» Davies, N. de G. (1923). “Akhenaton at Thebes.” Journal of Egyptian Archaeology, 9, 132-152.

»Davies, N. de G. (1941). The Tomb of Vizier Ramose. Londres: Archaeological Survey of Egypt.

»Dodson, A. e Ikram, S. (2008). The tomb in ancient Egypt. Royal and private sepulchers from the early dynastic period to the romans. Cairo: The American University in Cairo Press.

»Ezzamel, M. (2002). Accounting working for the state: Tax assessment and collection during the new kingdom, ancient Egypt. Accounting and Business Research, 32(1), 17-39.

»Ezzamel, M. (2009). Order and accounting as a performative ritual: Evidence from ancient Egypt. Accounting. Organizations and Society, 34(3-4), 348-380.

»Ezzamel, M. (2012). Accounting and Order. Nueva York, Londres: Routldge.

»Galán, J. M. (2009). El Reino Nuevo I: La construcción del imperio. En J. M. Parra Ortíz (Coord.), El antiguo Egipto. Sociedad, Economía, Política (pp. 301-388). Madrid: Marcial Pons.

»Geist, I. (2002). Antropología del ritual. México: ENAH/INAH.

» Gell, A. (2016[1998]). Arte y agencia. Una teoría antropológica. Serie Arte, estética e imagen. Buenos Aires: Paradigma Indicial, Editorial SB.

» Gillam, R. A. (2005). Performance and Drama in Ancient Egypt. Londres: Duckworth.

» Hamui Sutton, S. (2010). El ritual como performance. Enunciación, 16(1), 16-30.

»Hödel-Höenes, S. (2000) Life and Death in Ancient Egypt. Scenes from Private Tombs in New Kingdom Thebes. Londres: Cornell University Ithaca.

» Hölscher, U. (1931). Erscheinungsfenster und Erscheinungsbalkon im königlichen Palast. Zeitschrift für ägyptische Sprache und Altertumskunde, Zeitschrift für ägyptische Sprache und Altertumskunde, 67, 43-51. 
» Hornung, E. (2000). Introducción a la Egiptología. Estados, métodos, tareas. Madrid: Ed. Trotta.

" Kemp, B. (1976). The Window of Appearance at El-Amarna, and the Basic Structure of the City. Journal of Egyptian Archaeology, 62, 81-99.

»Kemp, B. (1978). Imperialism and Empire in New Kingdom Egypt (c. 1575-1087 B.C.). En P.D. A. Garnsey \& C. R. Whittaker (Eds.), Imperialism in the Ancient World. Cambridge: Cambridge University Press.

» Kemp, B. (1992). El antiguo Egipto. Anatomía de una civilización. Barcelona: Crítica.

» Kemp, B. (2013). The city of Akhenaten and Nefertiti. Amarna and its people. Londres: Thames \& Hudson.

» Kemp, B., Stevens, A., Dabbs, G. R., Zabecki, M. y Rose, J. C. (2013). Life, Death, and Beyond in Akhenaten's Egypt: Excavating the South Tombs Cemetery at Amarna. Antiquity, 87, 64-78.

" Lichtheim, M. (1988). Ancient Egyptian Autobiographies Chiefly of the Middle Kingdom: A Study and an Anthology. Freiburg y Göttingen: Universitätsverlag y Vandenhoeck \& Ruprecht.

» Manniche, L. (1994). The Tombs of the Nobles at Luxor. Cairo: The American University Press.

» Martin, G. T. (1993). The Hidden tombs of Memphis: New discoveries from the time of Tutankhamun and Ramesses the Great. Londres: Thames and Hudson.

»Naville, E. (1895-1908). The Temple of Deir el-Bahari. Londres: Egypt Exploration Fund.

" O'Connor, D. (1998). The City and the Word: Worldview and Built Forms in the Reign of Amenhotep III. En D. O'Connor y E. H. Cline (Eds.), Amenhotep III. Perspectives on His Reign (pp. 125-172). Ann Arbor: University of Michigan Press.

"Panofsky, E. (1972). Estudios sobre iconología. Madrid: Alianza.

»Panofsky, E. (2000). El significado de las artes visuales. Madrid: Alianza.

"Porter, B. y Moss, R. L. B. (1968). Topographical Bibliography of Ancient Egyptian Hieroglyphic Texts, Reliefs, and Paintings, vols. I, III y IV. Oxford: Griffith Institute.

»Posener, G. (1960). De la Divinité du pharaon. Paris: Cahiers de la Société Asiatique.

» Redford, D. B. (1976). The Palace of Akhenaten in the Karnak Talatat. En The Akhenaten Temple Project I. Initial Discoveries (pp. 122-136). Warminster: Aris \& Phillips.

》 Rosenvasser, A. (1972). Las ideas morales en el antiguo Egipto. Serie Bibliográfica 15. Buenos Aires: Instituto de Historia Antigua Oriental.

"Schulman, A. R. (1988) Ceremonial execution and public rewards. Some historical scenes on New Kingdom private Stelae Göttingen: Fraiburg Schweiz Vandenhoek \& Puprecht.

"Shechner, R. (2000). Performance: Teoría y prácticas interculturales. Buenos Aires: Libros de Rojas Universidad de Buenos Aires.

"Skorupski, J. (1985). Símbolo y teoría. México: Premia Editora.

"Städelman, R. (1973). Audienzhalle. Lexikon der Ägyptologie, I, 4.

"Stevens, A., Dabbs, G. R., Shepperson, M. y King Wetzel, M. (2015). The Cemeteries of Amarna, in Kemp, B. 'Tell el-Amarna, 2014- 15'. Journal of Egyptian Archaeology, 101, 17-27.

» Taylor, D. y Fuentes, M. (2011). Estudios avanzados de performance. México: Fondo de Cultura Económica. 
» Teeter, E. (2011). The Amarna Period. Practical Aspects of 'Monotheism'. En Religion and Ritual in Ancient Egypt. Cambridge: Cambridge University Press.

»Wilde, G. y Schamber, P. (Comps.) (2006). Simbolismo, ritual y performance. Antropología sociocultural. Buenos Aires: Paradigma Indicial, Editorial SB.

»Wreszinski, W. (1988 [1914-1935]). Atlas zur altägyptischen Kulturgeschichte, 2 vols. Genova: Slatkine.

»Yomaha, S. (2005). La ceremonia de recompensa durante el reformismo amarniano: el ritual en la Ventana de Aparición. (Tesis de Licenciatura inédita), Universidad Nacional de Córdoba, Argentina.

»Zingarelli, A. P. (2010). Performance y audiencias en el Egipto Faraónico. En Actas del V Coloquio Internacional Mito y Performance, de Grecia a la Modernidad (pp. 790-798). La Plata: Editorial de la Universidad Nacional de La Plata. 